\title{
Thuiskomen in Nederland: migratiegeschiedenis schrijven met Delpher
}

\begin{abstract}
Delpher is the largest collection of full-text Dutch-language digitised historical newspapers, books, journals and copy sheets for radio news broadcasts available on a website. This article shows the possibilities of Delpher for doing research on Dutch-Hungarian relations by showing the results of an explorative study on a part of the migration history of one Hungarian family in The Hague. The author shows some very specific parts of the micro history of this family based on the content of newspaper advertisements. These sources were identified by addresses, telephone numbers and unique names.

Keywords: Dutch-Hungarian relations, migration history, digital humanities
\end{abstract}

Wat te doen als nieuwkomer in een stad die iets of iemand nodig heeft? Zonder informeel sociaal netwerk is die aangewezen op het plaatsen van advertenties via verschillende media. Het traditionele prikbord bij de plaatselijke supermarkt lijkt anno 2020 nog steeds in gebruik, maar nu staan vooral de advertentiesite Marktplaats, groepen op Facebook en WhatsAppgroepen vol met hulpvragen van migranten en expats die net in ons land zijn aangekomen. Voor de komst van sociale media en internet was het natuurlijk minder eenvoudig om als vreemdeling om hulp te vragen. De snelste en goedkoopste weg was het plaatsen van een advertentie in een plaatselijke krant en dat werd dan ook massaal gedaan. 
De bekende Nederlandse site Delpher van de Koninklijke Bibliotheek Nationale Bibliotheek van Nederland is een goudmijn voor dergelijke advertenties. ${ }^{1}$ Het is een online database met miljoenen gedigitaliseerde teksten uit Nederlandse kranten, boeken en tijdschriften die woord voor woord doorzoekbaar zijn. ${ }^{2}$ De teksten komen uit de collecties van diverse wetenschappelijke instellingen, bibliotheken en erfgoedinstellingen. ${ }^{3} \mathrm{De}$ gedigitaliseerde collectie bestaat uit ongeveer 1,6 miljoen kranten, 14 miljoen krantenpagina's 4,4 miljoen tijdschriftpagina's en meer dan 500.000 boeken van de 15 de tot en met de 21 ste eeuw. ${ }^{4}$ In het totaal bevat Delpher meer dan 100 miljoen gedigitaliseerde pagina's.

Tot nu toe hebben de emotionele liefdesoproepen in krantenadvertenties de meeste aandacht gekregen. ${ }^{5}$ Vanuit het oogpunt van migratiegeschiedenis zijn de kleine advertenties het meest interessant en tot nu nog maar weinig gebruikt in dergelijk onderzoek. (Deze categorie is apart te selecteren als 'advertenties' bij de zoekmogelijkheden.)

Den Haag is wat micromigratiegeschiedenis betreft één van de meest interessante plaatsen in Nederland, omdat vanwege het grote aantal expats, diplomaten, buitenlandse spionnen (de bekende spionne Mata Hari!), arbeidsmigranten, vluchtelingen en repatrianten uit NederlandsIndië de lokale kranten een bonte verzameling van al dan niet wanhopige oproepen laten zien. Het enige lastige van het in kaart brengen van dergelijke geschiedenissen is dat de advertenties vaak anoniem zijn en alleen voorzien van een (summier) adres of (lokaal) telefoonnummer.

Dergelijke advertenties zijn tot nu toe nog niet veel gebruikt bij het onderzoek naar Hongaars-Nederlandse betrekkingen of het schrijven van de Hongaarse migratiegeschiedenis in Nederland. In dit artikel wil ik daarom de lotgevallen van een jong Hongaars migrantengezin net voor en tijdens de oorlogsjaren in Den Haag laten zien aan de hand van dergelijke advertenties. Dit zal ik aanvullen met gedigitaliseerde objecten uit die tijd van moderne musea en 'digitaal geboren' advertenties van makelaarssites uit onze tijd. Ik zal niet uitgebreid ingaan op hun herkomst of hun plaats in de 'grote geschiedenis': ik wil laten zien wat voor soort gedetailleerde informatie te achterhalen is uit advertenties. Ik hoop hiermee een aanzet te geven tot meer onderzoek naar de migratiegeschiedenis van Hongaren in Nederland.

Mijn werkwijze was als volgt: eerst heb ik de migratiegeschiedenis in kaart gebracht aan de hand van het Rotterdamse en Haagse bevolkingsregister en de genealogische site Wiewaswie. ${ }^{6}$ Daarna heb ik de precieze adressen gelokaliseerd op basis van de gedigitaliseerde telefoonboeken in 
Delpher. Vervolgens heb ik gezocht op adres en ook op het telefoonnummer. Beide vormden unieke "identifiers" die zo te verbinden waren aan één gezin.

Het desbetreffende gezin was rond 1937 verhuisd van Boedapest in Hongarije naar Rotterdam. De man des huizes was directeur van een Rotterdamse rubberonderneming Interrub, een dochteronderneming van een groot bedrijf in Hongarije. ${ }^{7}$ Hij vestigde zich met zijn familie in een rijtjeshuis aan de Krommelaan 3 in Overschie bij Rotterdam en het kantoor van het bedrijf stond in de Rotterdamse binnenstad. Na het bombardement op Rotterdam tijdens de meidagen in 1940 wilde het gezin opnieuw verhuizen en plaatsten ze in september 1940 de volgende advertentie in de krant Het Vaderland. ${ }^{8}$

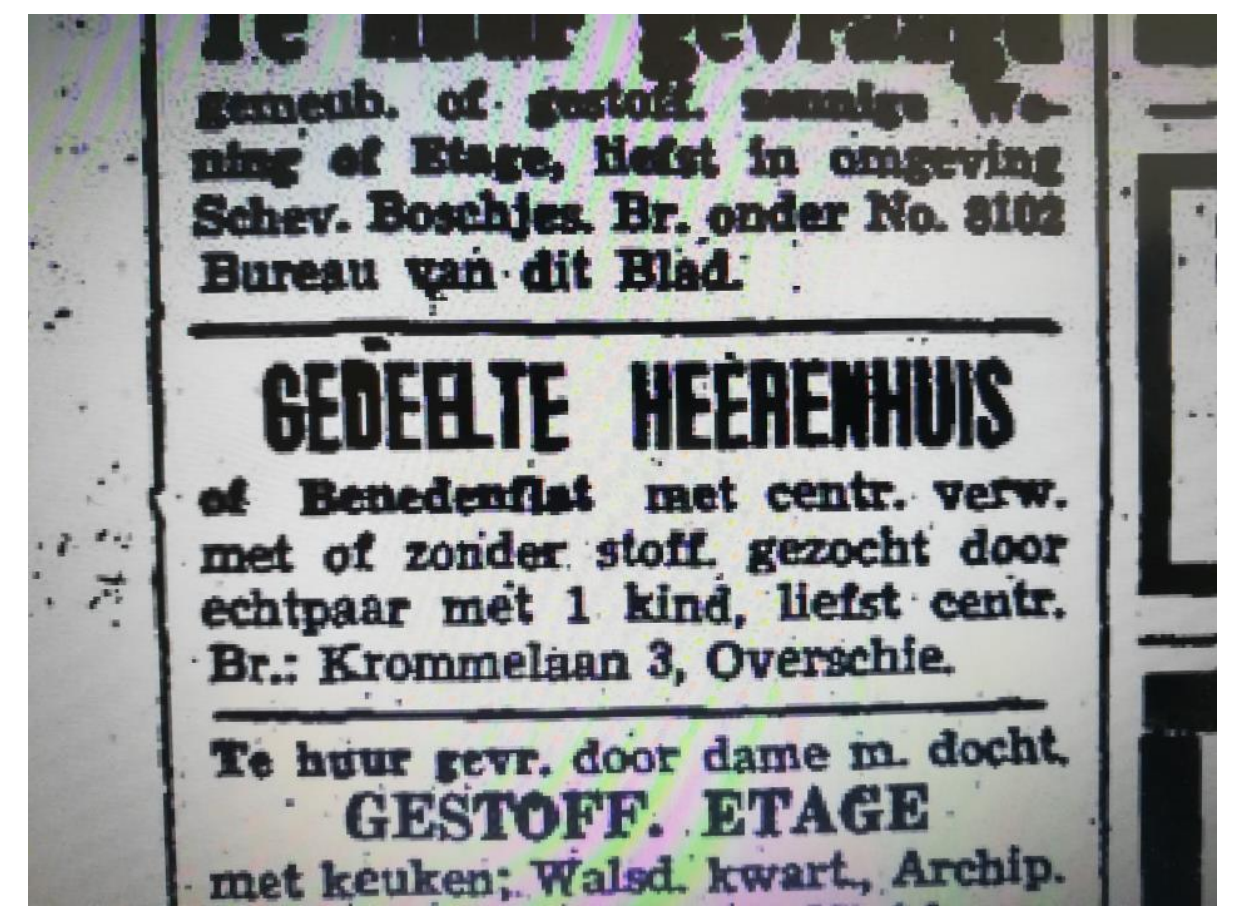

Foto 1. Advertentie

De zoektocht naar een "heerenhuis" was natuurlijk moeilijk in de oorlogsjaren en zeker in het gebombardeerde Rotterdam. Uiteindelijk kwam het gezin daarom waarschijnlijk terecht in een benedenwoning aan de rand van bebouwd Den Haag. 


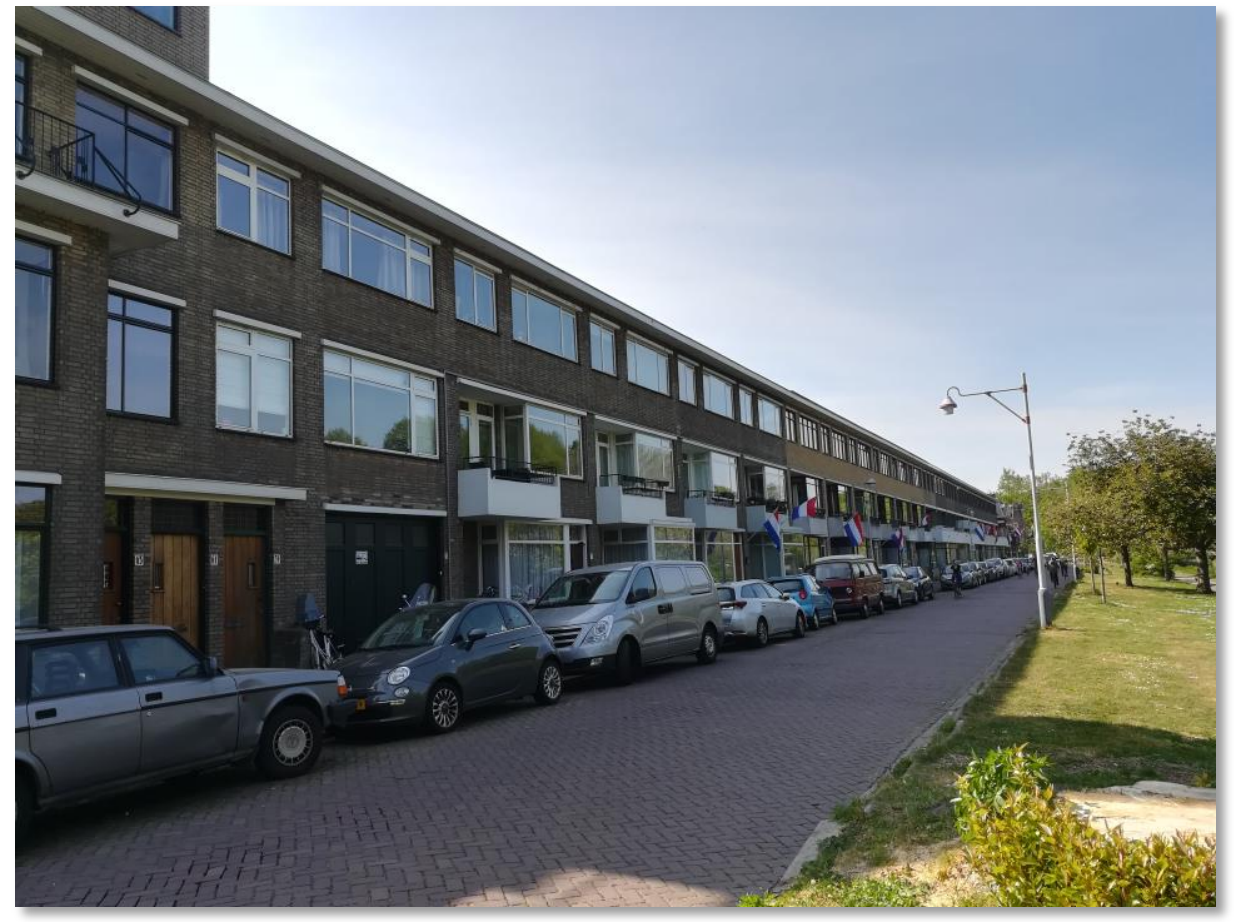

Foto 2. De straat van het huis anno 2020

Het nieuwe adres werd Carel Reinierszkade 257 in de wijk 'Bezuidenhout': een Haagse nieuwbouwwijk die tijdens het Interbellum langzaam werd volgebouwd. Het huis keek uit over de weilanden en stond om de hoek van het koninklijk paleis Huis ten Bosch aan de Bezuidenhoutseweg. ${ }^{9}$ Op dit adres was ook de onderneming gevestigd, zoals blijkt uit de gedigitaliseerde telefoongids uit $1943 .{ }^{10}$ Het is niet duidelijk of het kantoor daarmee ook aan huis werd gehouden. Op basis van de moderne gegevens van een makelaarssite lijkt het een vierkamerwoning te zijn geweest met twee slaapkamers. ${ }^{11}$ Uit een advertentie van het (toevallig) recent verkochte appartement krijgen we een goed beeld wat de jaren '30 sfeer moet zijn geweest van dit huis. ${ }^{12}$ 


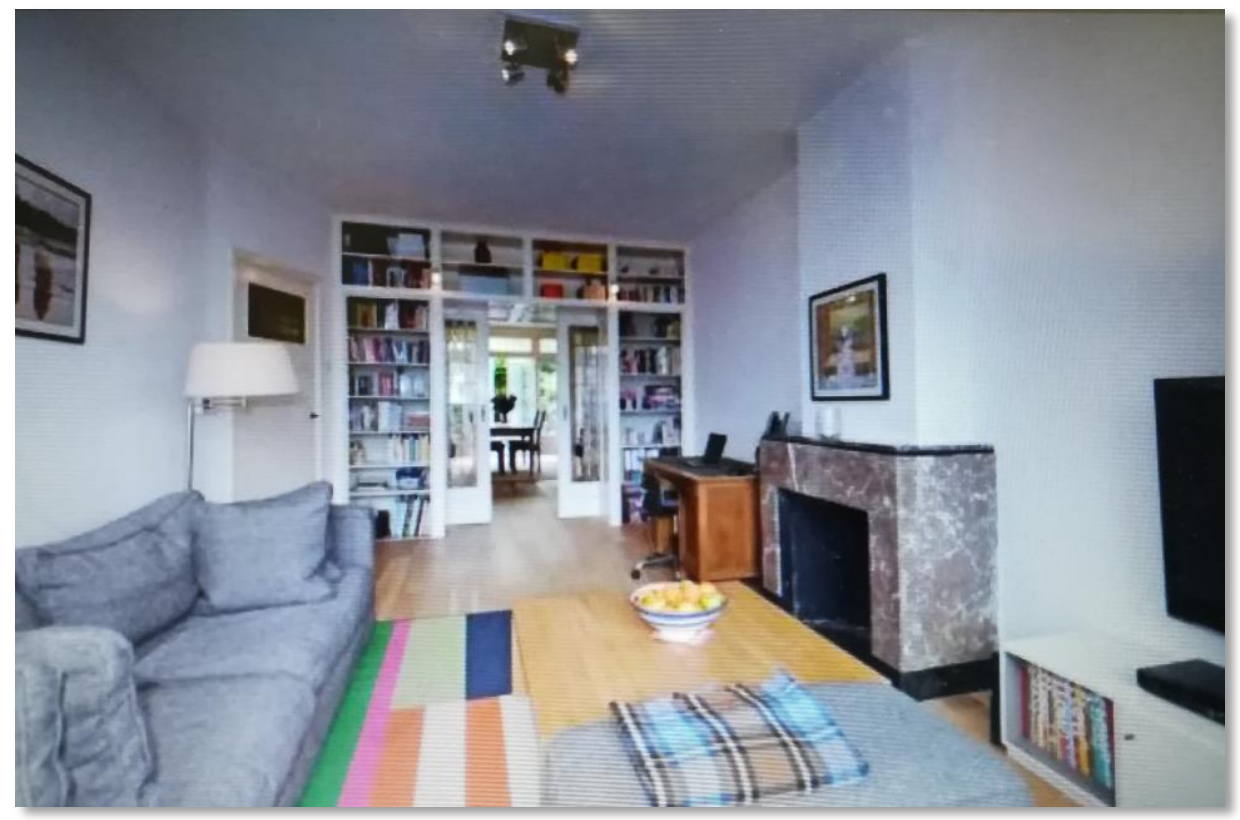

Foto 3. Interieur

Opvallend is dat ook in de inrichting in 2020 ruimte is gemaakt voor een jaren ' 30 of ' 40 bureau in de woonkamer, net als dat in de tijd van het Hongaarse gezin het geval zal zijn geweest.

Al vermeldde de advertentie expliciet dat het gezin één kind had, toch kon het huishouden wel wat hulp gebruiken. Op 14 januari 1943 verscheen daarom de volgende oproep in Het Vaderland voor een "ervaren dagmeisje in klein gezin, volle kost en hoog loon". ${ }^{13}$ (Voor een dienstje voor dag- en nacht was geen dienstbodenkamer beschikbaar.)

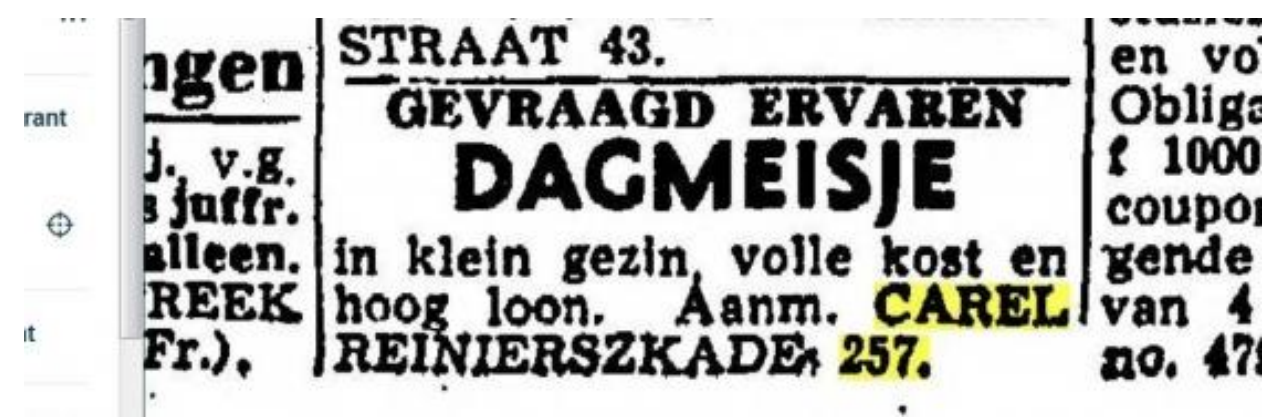

Foto 4. Advertentie dagmeisje 


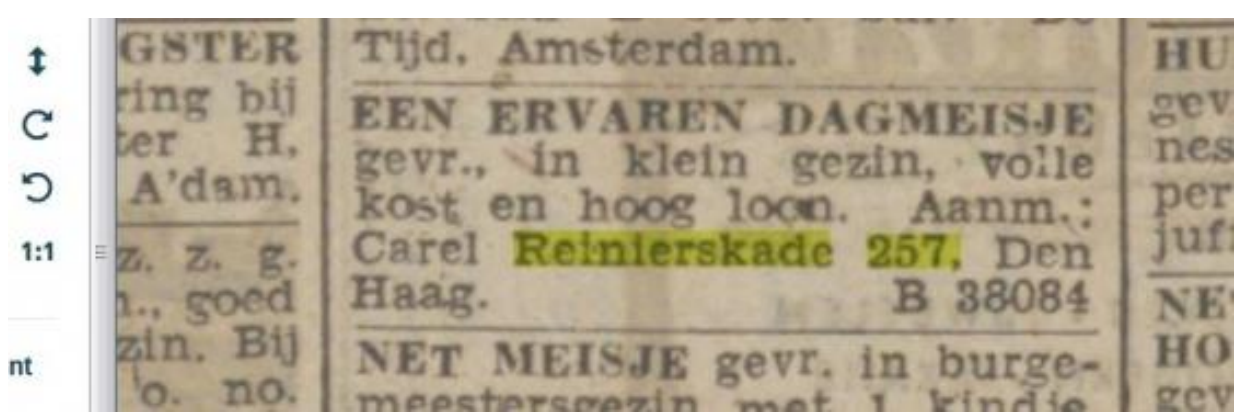

Foto 5. Tweede advertentie

Waarschijnlijk had de oproep geen succes. Daarom verscheen een week later op 23 januari 1943 een nieuwe advertentie, ditmaal in dagblad De Tijd. ${ }^{14}$

Bij het bestuderen van microgeschiedenis van een gezin komt de historicus meestal niet achter de deuren van intieme ruimtes als de badkamer of de slaapkamer (behalve dan in onze tijd via de makelaarssite Funda). Toch kwam de deur op een kier van het slaapvertrek op de Carel Reinierszkade door een advertentie die op 26 januari 1943 ook werd afgedrukt in De Tijd. De Vrouw des Huizes vroeg hierin om een "compleet slaapkamerameublement, alleen goede kwaliteit, niet ouderwetsch" ${ }^{15}$

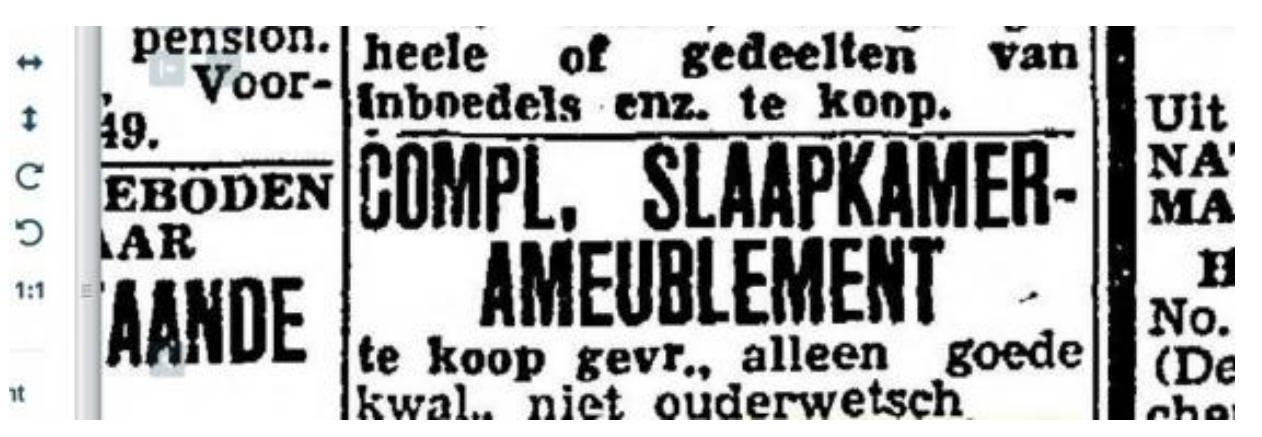

Foto 6. Advertentie Slaapkamerameubelement

Uit de tekst "niet ouderwetsch" kunnen we opmaken dat de smaak van dit gezin niet moet zijn uitgegaan naar de degelijke en fraai ontworpen, maar ook wat ouderwets aandoende meubelen van de bekende Haagse meubelen vliegtuigfabriek Pander. ${ }^{16}$ Het is waarschijnlijker dat het gewenste bed van het merk Gispen kan zijn geweest, waarvan de meubelen meer eigen- 
tijds van vormgeving waren. ${ }^{17}$ Hoe een moderne slaapkamer van goede kwaliteit eruit moet hebben gezien kunnen we opmaken uit een poppenslaapkamer uit 1940 afkomstig uit de collectie van het Museum Deventer. ${ }^{18}$

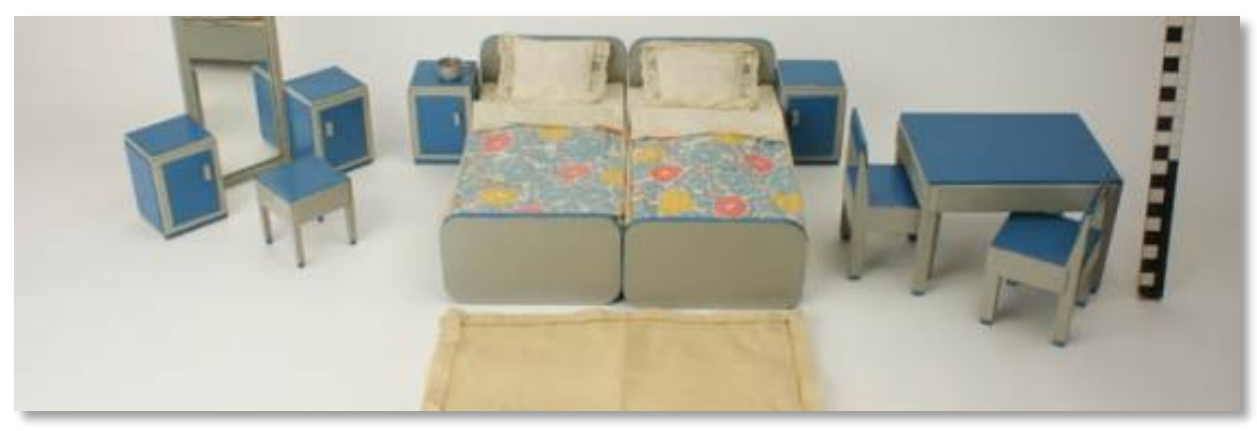

Dat de vorige oproep succes had gehad, valt op te maken uit de advertentie die op 25 mei 1943 verscheen in Het Vaderland. ${ }^{19}$ De deur van de slaapkamer staat nu echt op een kier, want het gedroomde bed is een moderne lits-jumeaux geworden. De echtgenote is nu op zoek naar een sprei voor dit bed, het liefst in de kleur zacht groen of rose.

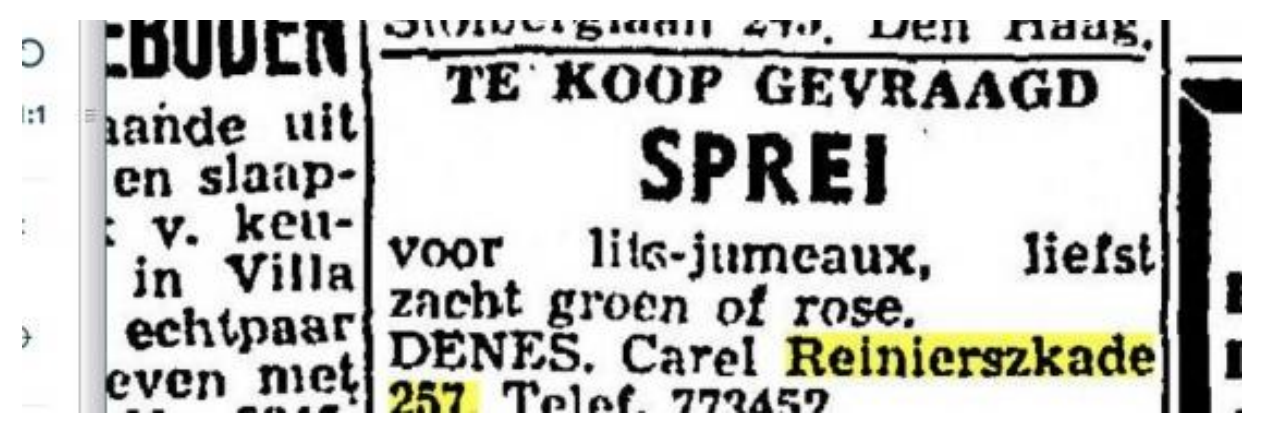


Een lits-jumeaux bestond uit twee éénpersoonsbedden die naast elkaar stonden. Wikipedia geeft vervolgens een mooi beeld van hoe die slaapkamer op de Carel Reinierszkade er dan uit kan hebben gezien in een uitvoering van Gispen uit $1933 .^{20}$

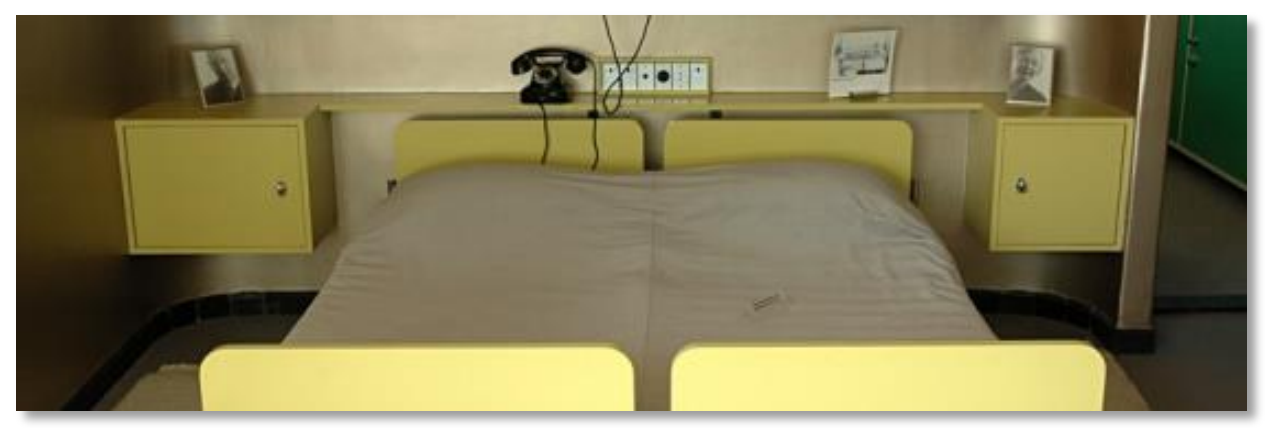

Foto 9. Van Gispen slaapkamer

Dankzij de foto in de moderne makelaarsadvertentie krijgen we ook een beeld hoe die slaapkamer op de begane grond eruit zag. ${ }^{21}$

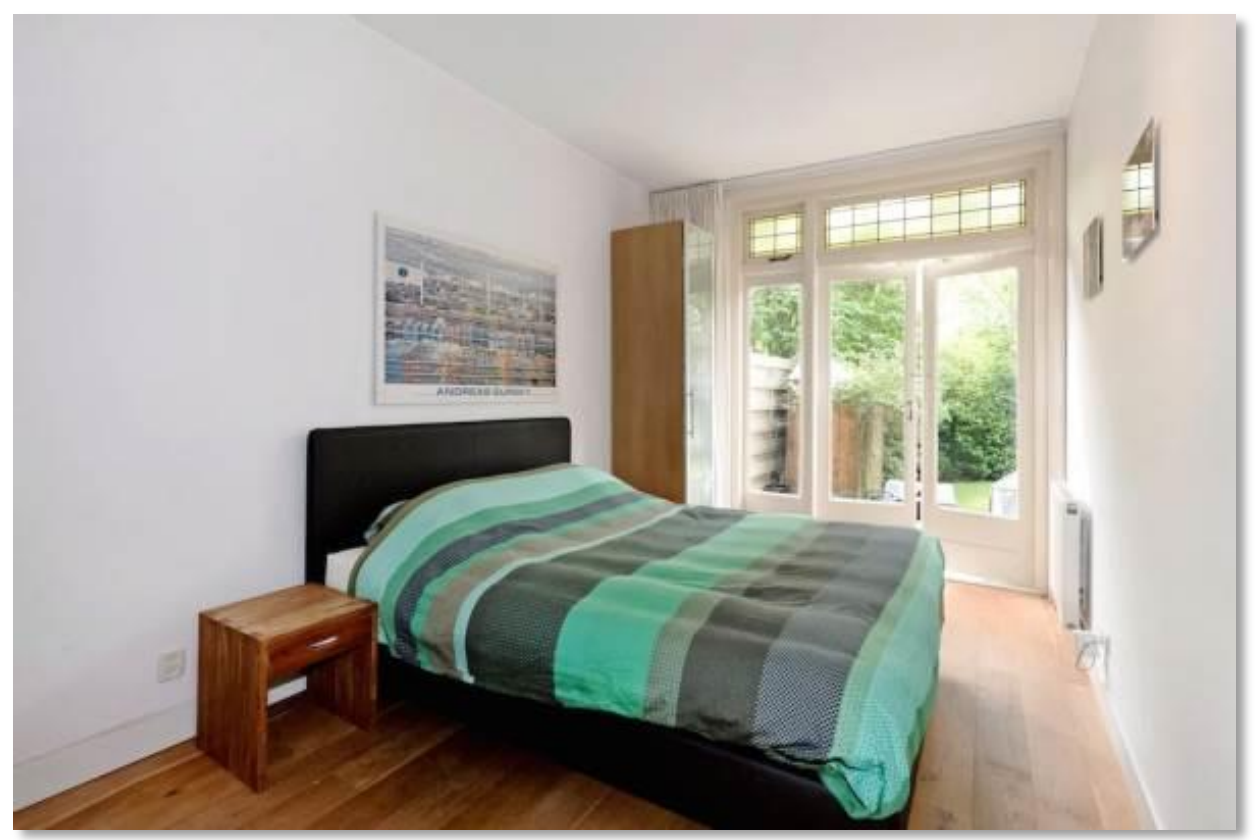

Foto 10. De slaapkamer anno 2020 
Misschien wel mede dankzij de comfortabele lits-jumeaux bloeide het gezinsleven in den vreemde. De Hongaarse traditie is dat met Kerst cadeautjes worden uitgewisseld, die in gezinnen met kleine kinderen op Kerstavond door de Hongaarse "Jézuska" ("kleine Jezus" of het Christuskind) onder de kerstboom worden gelegd. Uit een advertentie die op 29 november 1943 is geplaatst, kunnen we opmaken wat de bedoeling was dat met Kerst 1943 onder de Haagse kerstboom terecht zou komen. ${ }^{22}$

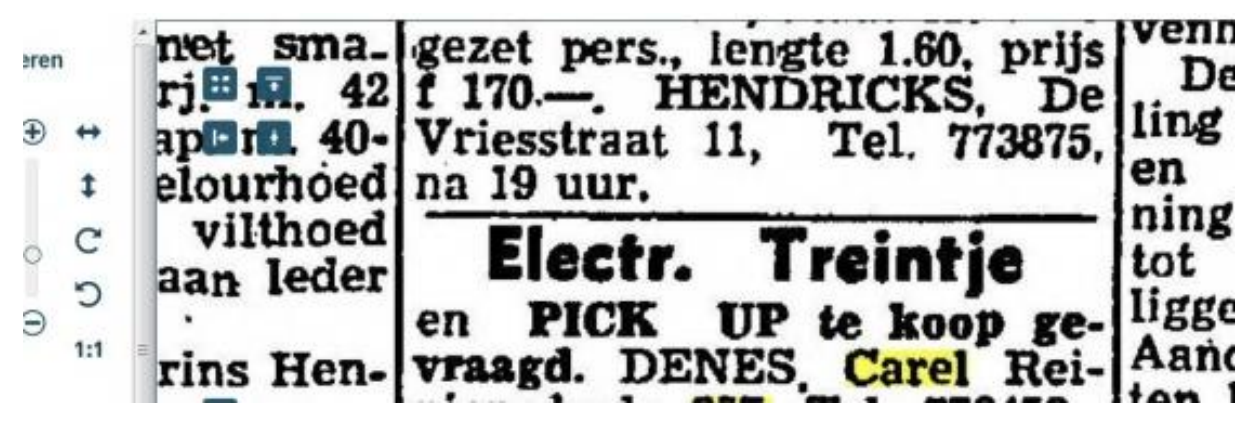

Foto 11. Advertentie treintje en pick up

Het is lastig om na te gaan wat de gewenste pick-up voor manlief is geweest, al kan op basis van de Hongaarse muzieksmaak uit die tijd ervan uit worden gegaan dat daar bakelieten langspeelplaten van bijvoorbeeld Katalin Karády en Pál Jávor op hebben gedraaid. Een gangbaar merk elektrische trein uit die tijd was het Duitse Märklin. Het gewenste "treintje" kan er dan zo uit hebben gezien. ${ }^{23}$

Een van de moeilijke zaken bij onderzoek naar inburgering van migranten is de vraag hoe de mate van inburgering nu te meten is. Taalkennis is een belangrijke factor, maar dit blijkt natuurlijk niet uit de advertenties, want die bestaan meestal uit standaardteksten die waarschijnlijk door een telefoniste werden opgenomen en waar nodig verbeterd. (Daarom zitten er waarschijnlijk meer spelfouten in namen van geboorte- en overlijdensadvertenties dan in de gewone oproepen.)

We krijgen wel een 'kijkje in de inburgeringskeuken' door een advertentie die op 1 december 1943 is geplaatst. De vrouw des huizes is nu op zoek naar een eetkamerameublement en een "mooie antieke rankenkast". ${ }^{24}$ 


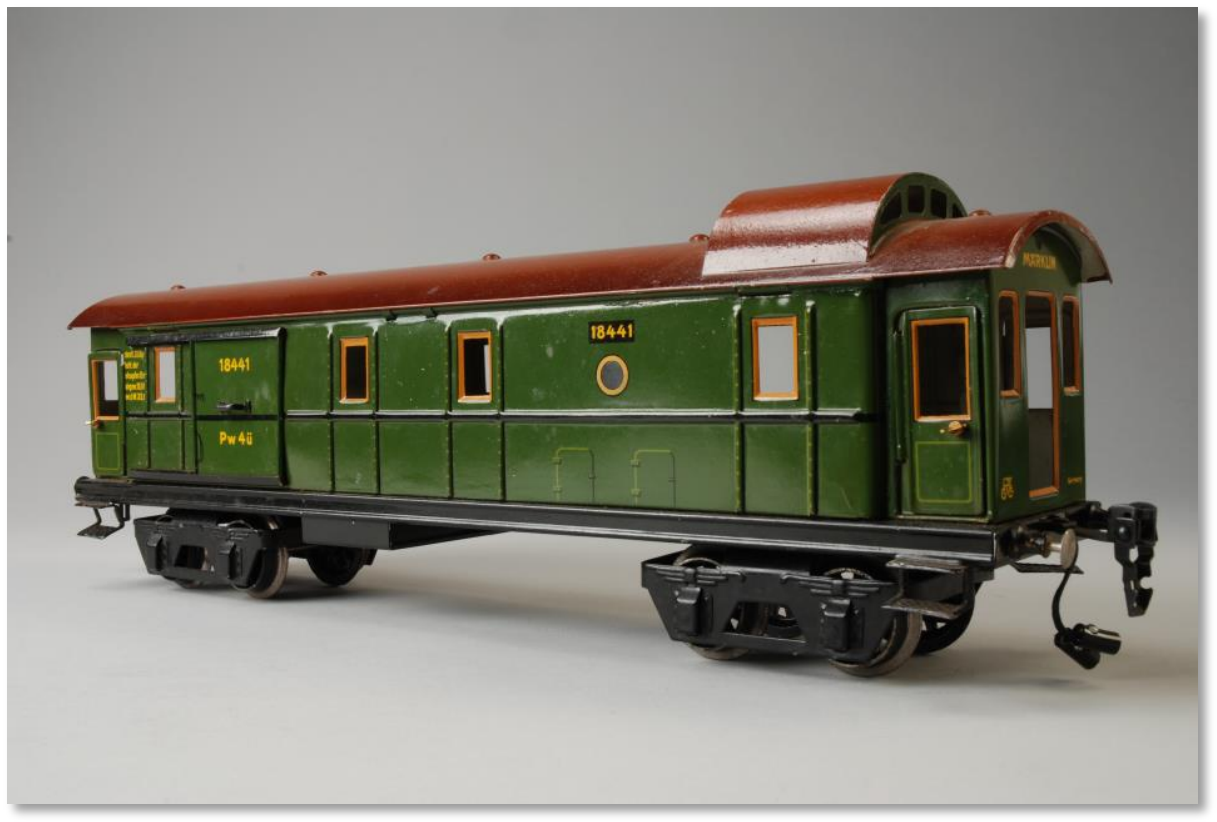

Foto 12. Treintje, collectie Museum Rotterdam

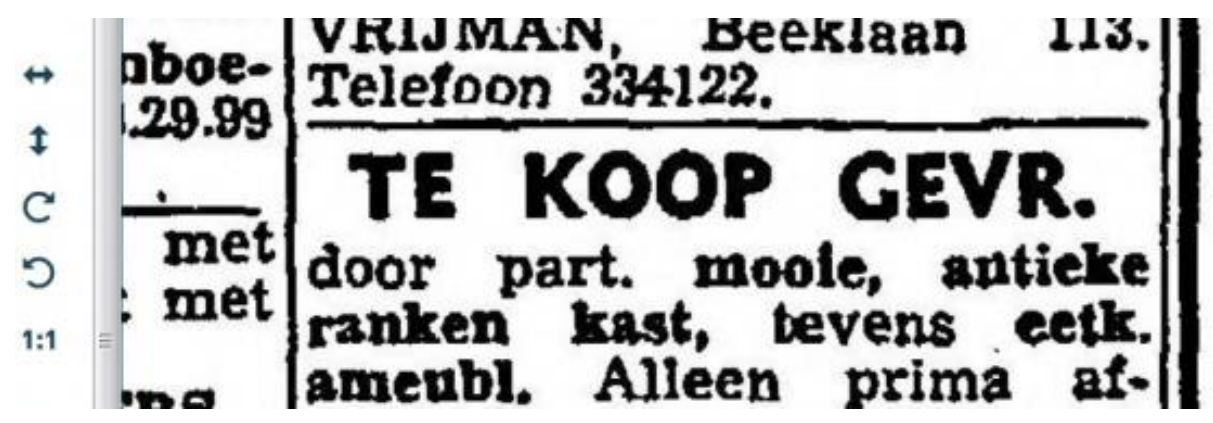

Foto 13. Advertentie rankenkast

De eetkamertafel en stoelen zullen wel een eigentijdse set zijn geweest, misschien opnieuw van het merk Gispen. De keuze voor een antieke rankenkast in de huiskamer is opmerkelijk gezien de moderne smaak van de huisvrouw, zie bijvoorbeeld de rankenkast uit de collectie van Museum Rotterdam. $^{25}$ 


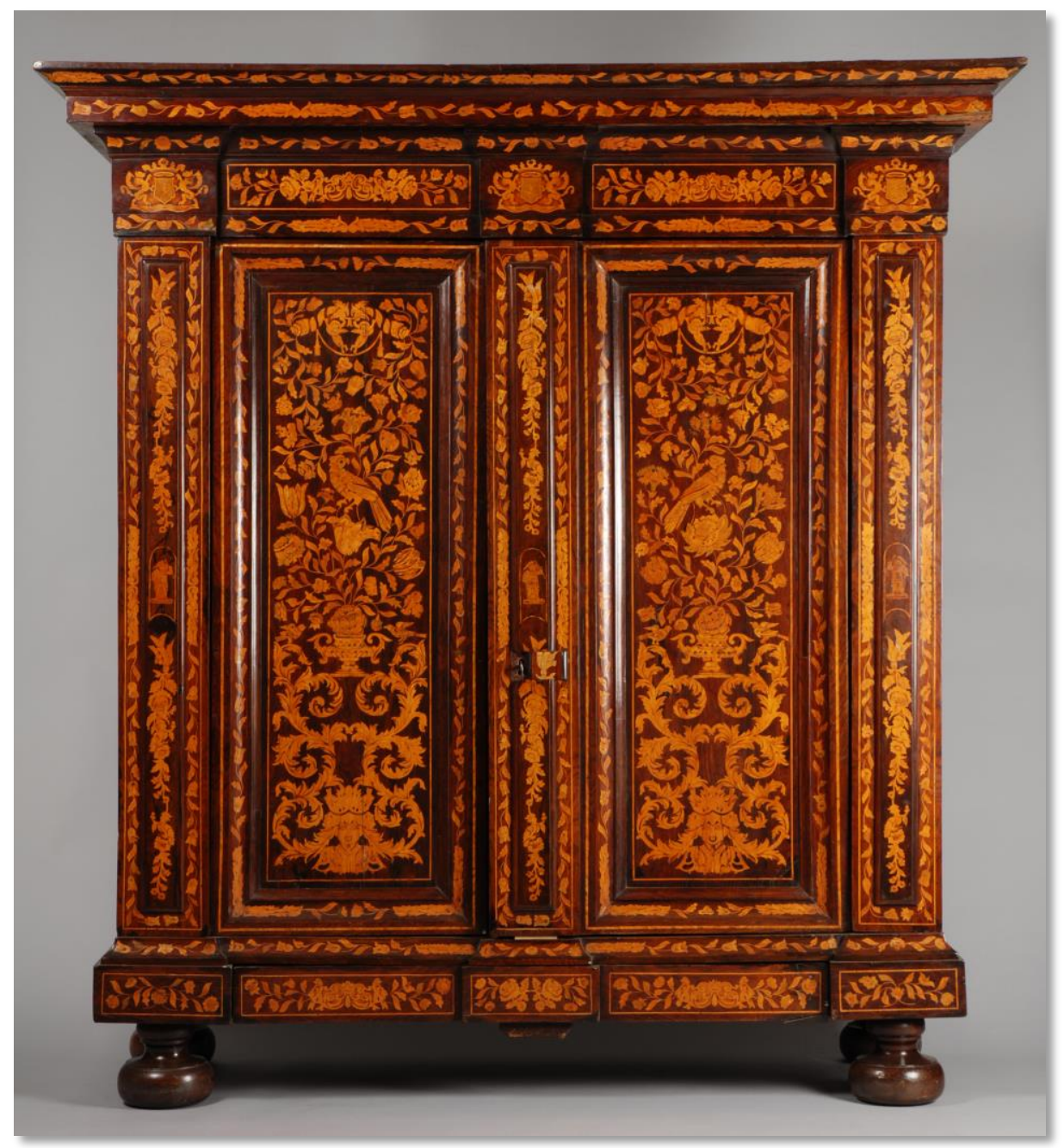

Foto 14. Rankenkast, collectie Museum Rotterdam

Dit meubel moest misschien de pas verworven sociale status van het migrantengezin in het gastland laten zien, maar kan ook de verbondenheid met de Nederlandse cultuur hebben benadrukt. Het was wellicht ook een teken dat deze migranten wisten hoe het hoorde in een net "Hollandsch huisgezin" van goede komaf.

Ondanks de oorlog in Nederland en de zorgen om de achtergebleven familie in Hongarije (het land is inmiddels bezet door de Duitsers en wordt aangevallen door de Sovjet-Unie) is er toch ook aandacht voor ont- 
spanning en "vacantie". Op 10 juni 1944 verschijnt een advertentie waarin een kleine familie, bestaande uit man, vrouw, kind en dienstbode op zoek zijn naar een zomerverblijf tussen 10 en 25 juli, "het liefst aan het water". Eventueel is het mogelijk om het gewenste verblijf te ruilen met de woning in Den Haag. De herkomst van deze advertentie wordt alleen verraden door het gebruikte lokale telefoonnummer $773452 .{ }^{26}$

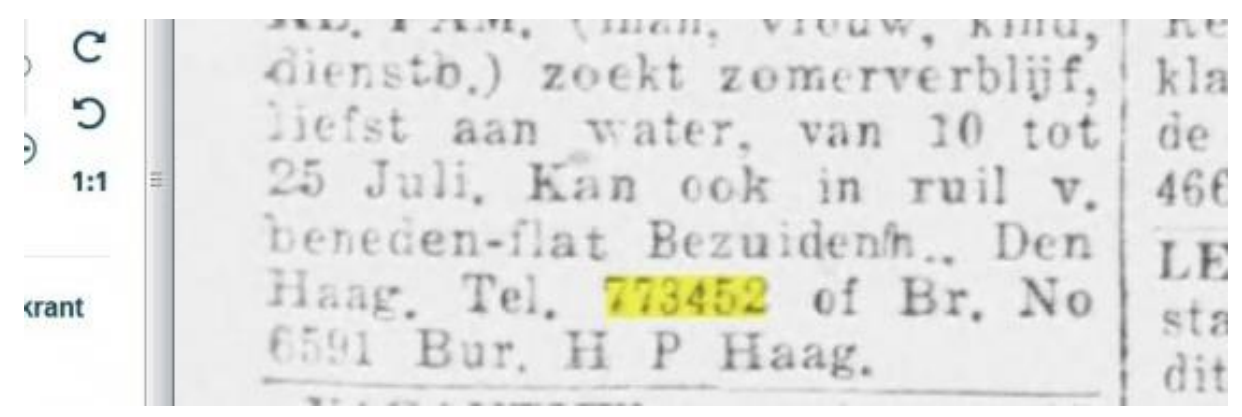

Foto 15. telefoonnummer

Zomer 1944 is waarschijnlijk de laatste rustige en relatief onbezorgde periode voor dit gezin geweest. Na september verschijnen er geen advertenties meer met hun adres of telefoonnummer. Het laatste bericht is een oproep voor een paar rolschaatsen 'voor een jongen van 10 jaar'. ${ }^{27}$

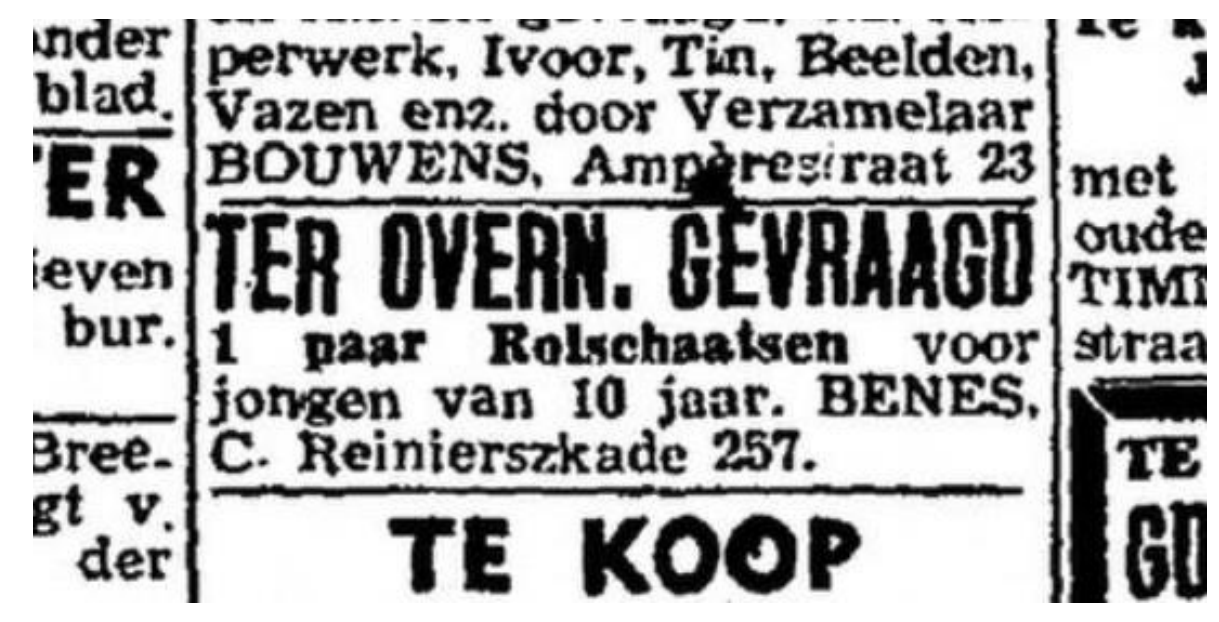

Foto 16. Rolschaatsen gevraagd 


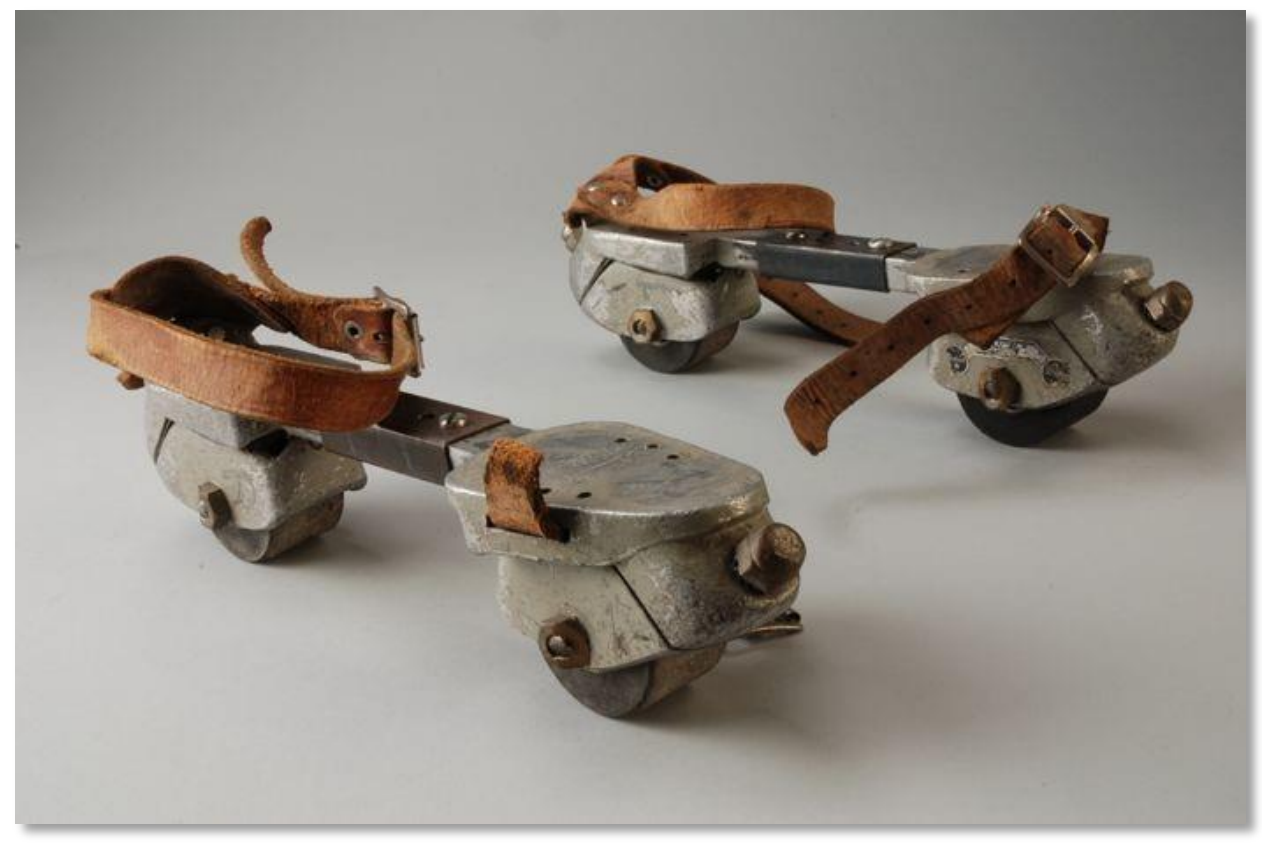

Foto 17. Rolschaatsen, Museum Rotterdam

Deze rolschaatsen kunnen van het type zijn geweest zoals die rond de oorlog te koop waren in het nabijgelegen Voorburg en nu een set zich in de collectie van het Museum Rotterdam bevindt. ${ }^{28}$

De rolschaatsen konden goed gebruikt worden, zoals blijkt uit een moderne foto van de hal oorspronkelijke tegels uit de jaren dertig ${ }^{29}$ en het nauwelijks veranderde uitzicht sinds de Tweede Wereldoorlog vanuit de voordeur naar de stoep van de straat. $^{30}$

De kinderrolschaatsen zijn het laatste tastbare spoor van het rustige gezinsleven. Uit een nieuwsbericht in de illegale krant Het Parool die werd gedrukt op 11 december 1944 blijkt dat de verschrikkingen van de oorlog nu ook het chique en rustige Bezuidenhout hadden bereikt. Op 6 december 1944 kwamen bommen neer op huizen aan de Carel Reinierszkade, waarschijnlijk aan de andere zijde dan de kant van de woning. ${ }^{31}$ 


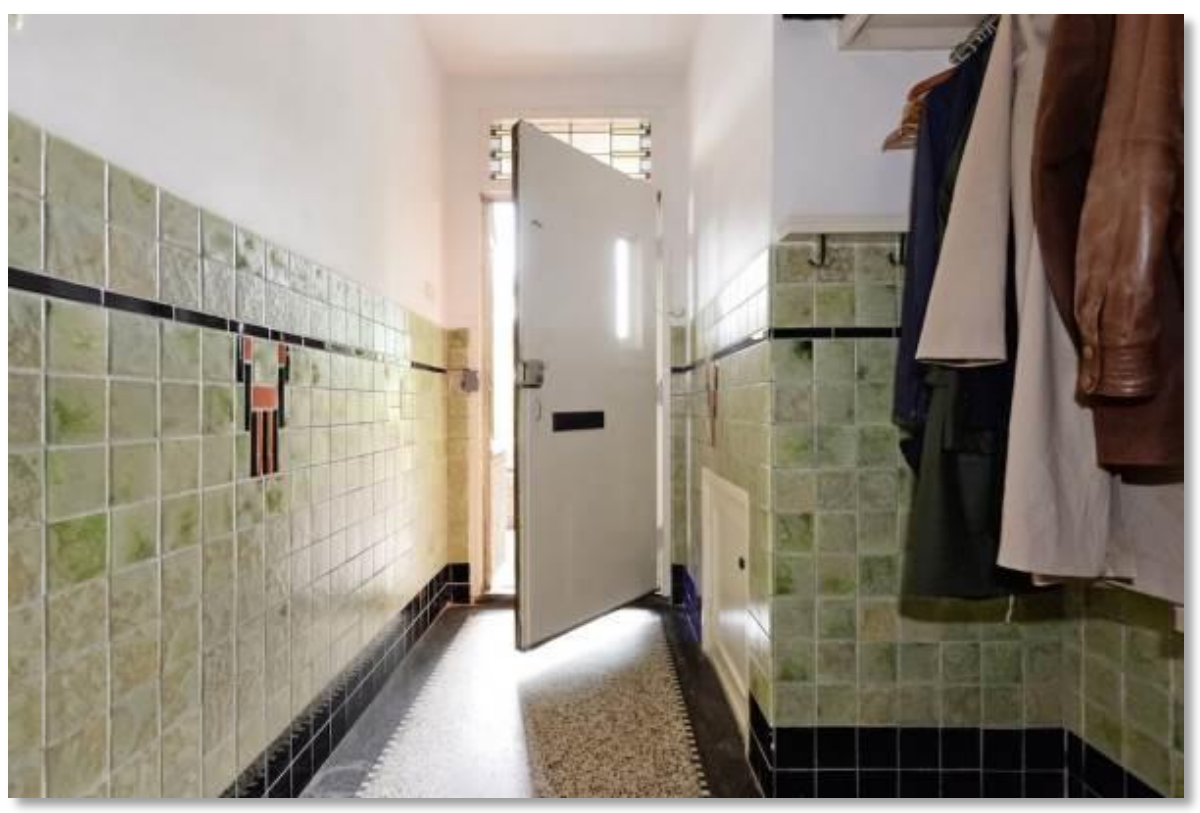

Foto 18. Voordeur

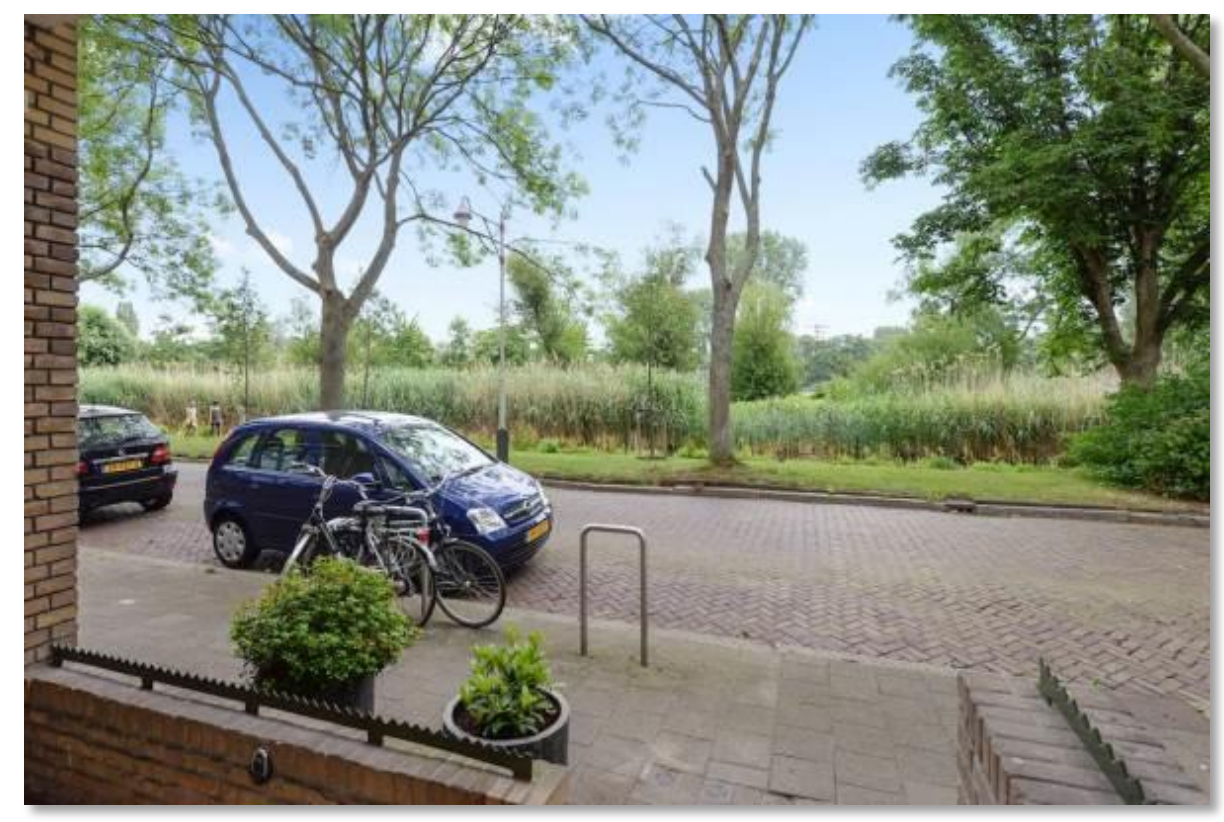

Foto 19. Stoep. 
Dit was niet de laatste schrik voor de straat en het gezin: op 3 maart 1945 vond het bekende "Bombardement op het Bezuidenhout" plaats. Uit de plattegronden van de gebombardeerde wijk blijkt dat het huis aan de Carel Reinierszkade maar ternauwernood aan de verwoesting is ontsnapt. ${ }^{32}$ De laatste vermelding over het gezin is een overlijdensadvertentie gedateerd op 12 november 1945, waaruit blijkt dat de man van het gezin onverwacht is overleden. ${ }^{33}$ Hier wordt ook voor het eerst de volledige naam van de man gebruikt: Ladislaus Erwin Teszelszky Dénes. Vanwege de communistische machtsovername in Hongarije is het gezin waarschijnlijk nooit meer naar Hongarije teruggekeerd en zijn nazaten wonen nog steeds in Den Haag en omgeving, waaronder de auteur van dit artikel.

De gedigitaliseerde krantendatabase Delpher is niet alleen interessant om op zoek te gaan naar bekende personen, grote gebeurtenissen of de eigen particuliere familiegeschiedenis, maar kan door het bestuderen van advertentieteksten ook een intiem beeld van het gezinsleven van relatief onbekende Hongaarse nieuwkomers in de Nederlandse samenleving opleveren. De advertentieteksten in Nederlandse kranten bevatten een schat aan onbekende informatie over de migratiegeschiedenis van Hongaren in Nederland die tot nieuwe inzichten kan leiden in de toekomst.

Noten

1 Koninklijke Bibliotheek, 2020. Delpher. (https://www.delpher.nl/) (laatst geraadpleegd op 9 april 2020)

2 Koninklijke Bibliotheek, $2020 . \quad$ Delpher. (https://www.delpher.nl/nl/platform/pages/helpitems?title=wat+is+delpher) (laatst geraadpleegd op 9 april 2020)

3 Koninklijke Bibliotheek, $2020 . \quad$ Delpher. (https://www.delpher.nl/nl/platform/pages/helpitems?title=partners\&scrollitem=true) (laatst geraadpleegd op 9 april 2020)

4 Koninklijke Bibliotheek, 2020. Archief AD (én 150.000 andere kranten) toegevoegd aan Delpher. (https://www.kb.nl/nieuws/2020/archief-ad-en-150000-andere-krantentoegevoegd-aan-delpher) (laatst geraadpleegd op 9 april 2020)

5 Remie, 'Liefdesoproepen uit vervlogen tijden', 3.

6 Wiewaswie, 2020. https://www.wiewaswie.nl/ (laatst geraadpleegd op 9 april 2020)

7 Pataki, Gumiipari vállalatok repertóriuma, 17-18, 31, 41, 101.

8 Het Vaderland. 07-09-1940: 4.

9 https://www.google.nl/maps/place/Carel+Reinierszkade+257,+2593+HR+Den+Ha 
ag/@52.0854031,4.3470205,17z/data=!3m1!4b1!4m5!3m4!1s0x47c5b7a0b85d7195: 0xebabaede139c7f4d!8m2!3d52.0853998!4d4.3492092 (laatst geraadpleegd op 9 april 2020)

10 Naamlijst voor den interlocalen telefoondienst 1942, 3490. https://resolver.kb.nl/resolve?urn=MMMVC01:000000035:00077 (laatst geraadpleegd op 9 april 2020)

11 Advertentie.

https://www.oozo.nl/woningen/sgravenhage/bezuidenhout/bezuidenhout-oost/woning/832422/woning-carelreinierszkade-257-den-haag (laatst geraadpleegd op 9 april 2020)

12 Internet Archive Wayback Machine https://web.archive.org/web/20200220114053/https://cdn.binqmedia.nl/Woonwijs/20 17/9/10/1049378240/6.jpg_(laatst geraadpleegd op 9 april 2020)

13 Het Vaderland. 14-01-1943: 2.

14 De Tijd. 23-01-1943: 6.

15 Het Vaderland. 26-01-1943: 2.

16 Pander. https://nl.wikipedia.org/wiki/Pander (laatst geraadpleegd op 9 april 2020)

17 Stichting Gispen Collectie. https://www.stichtinggispencollectie.nl/collectie/producten (laatst geraadpleegd op 9 april 2020)

18 Deventer Musea. http://www.collectiedeventermusea.nl/Details/collect/209213 (laatst geraadpleegd op 9 april 2020)

19 Het Vaderland. 25-05-1943: 2.

20 Lits-jumeaux. https://nl.wikipedia.org/wiki/Lits-jumeaux\#/media/Bestand:WLANL__p_vanderree_-_Bed_756,_W.H._Gispen_(1933).jpg (laatst geraadpleegd op 9 april 2020)

21 Internet

Archive

Wayback

Machine https://web.archive.org/web/20200220115731/https://cdn.binqmedia.nl/Woonwijs/20 17/9/10/1049378240/18.jpg (laatst geraadpleegd op 9 april 2020)

22 Het Vaderland. 29-11-1943: 4.

23 Museum Rotterdam, inventarisnummer 30009-6. https://museumrotterdam.nl/collectie/item/30009-6 (laatst geraadpleegd op 9 april 2020)

24 Het Vaderland. 01-12-1943: 2.

25 Museum Rotterdam, inventarisnummer 8306. https://museumrotterdam.nl/collectie/item/8306 (laatst geraadpleegd op 9 april 2020)

26 Haagsche post. 10-06-1944: 13.

27 Het Vaderland. 27-09-1944: 2.)

28 Museum Rotterdam, inventarisnummer 79736-A-B https://museumrotterdam.nl/collectie/item/79736-A-B (laatst geraadpleegd op 9 april 2020)

29 Internet

Archive

Wayback

Machine https://web.archive.org/web/20200220114412/https://cdn.binqmedia.nl/Woonwijs/20 17/9/10/1049378240/22.jpg (laatst geraadpleegd op 9 april 2020) 
30 Internet Archive Wayback Machine https://web.archive.org/web/20200220114532/https://cdn.binqmedia.nl/Woonwijs/20 17/9/10/1049378240/23.jpg (laatst geraadpleegd op 9 april 2020)

31 Anoniem, 'Nieuws uit Den Haag', 11-12-1944: 2.

32 Anoniem, 'Bombardement op het Bezuidenhout' https://anemaa.home.xs4all.nl/ges/onderwerpen/bombardement_bezuidenhout_3_bo mbardement.htm (laatst geraadpleegd op 9 april 2020)

33 Anoniem, 'Familieadvertentie', 4.

\section{Bibliografie}

Anoniem. 'Nieuws uit Den Haag.' Het Parool: speciaal nieuwsbulletin voor 's-Gravenhage en omstreken. 11-12-1944: 2.

Pataki, J. 2005. Gumiipari vállalatok repertóriuma. (A Magyar Országos Levéltár segédletei, 21.) Budapest: Magyar Országos Levéltár

Het Vaderland: staat- en letterkundig nieuwsblad. 07-09-1940: 4.

Het Vaderland: staat- en letterkundig nieuwsblad. 01-12-1943: 2.

Het Vaderland: staat- en letterkundig nieuwsblad. 14-01-1943: 2.

De Tijd: godsdienstig-staatkundig dagblad. 23-01-1943: 6.

Het Vaderland: staat- en letterkundig nieuwsblad. 26-01-1943: 2.

Het Vaderland: staat- en letterkundig nieuwsblad. 25-05-1943: 2.

Het Vaderland: staat- en letterkundig nieuwsblad. 29-11-1943: 4.

Het Vaderland: staat- en letterkundig nieuwsblad. 27-09-1944: 2.

Haagsche post: een Hollands weekblad. 10-06-1944: 13.

Mirjam Remie, 'Liefdesoproepen uit vervlogen tijden'. NRC Handelsblad. 10-02-2017: 3.

\section{Internetbronnen}

Advertentie. https://www.oozo.nl/woningen/s-gravenhage/bezuidenhout/ bezuidenhout-oost/woning/832422/woning-carel-reinierszkade-257den-haag (laatst geraadpleegd op 9 april 2020)

Anoniem, 'Familieadvertentie.' Algemeen Handelsblad. 12-11-1945: 4. https://resolver.kb.nl/resolve?urn=KBNRC01:000043266:mpeg21:a00 58

Anoniem, Bombardement op het Bezuidenhout, Geschiedenis van Den Haag. 
https://anemaa.home.xs4all.nl/ges/onderwerpen/bombardement_bezuid enhout_3_bombardement.htm (laatst geraadpleegd op 9 april 2020)

Deventer

Musea.

http://www.collectiedeventermusea.nl/Details/collect/209213 (laatst geraadpleegd op 9 april 2020)

Google

Maps.

https://www.google.nl/maps/place/Carel+Reinierszkade+257,+2593+H R+Den+Haag/@ 52.0854031,4.3470205,17z/data=!3m1!4b1!4m5!3m4 !1s0x47c5b7a0b85d7195:0xebabaede139c7f4d!8m2!3d52.0853998!4d 4.3492092 (laatst geraadpleegd op 9 april 2020)

Internet Archive Wayback Machine https://web.archive.org/web/20200220115731/https://cdn.binqmedia.nl /Woonwijs/2017/9/10/1049378240/18.jpg (laatst geraadpleegd op 9 april 2020)

Internet Archive Wayback Machine https://web.archive.org/web/20200220114412/https://cdn.binqmedia.nl /Woonwijs/2017/9/10/1049378240/22.jpg (laatst geraadpleegd op 9 april 2020)

Internet Archive Wayback Machine https://web.archive.org/web/20200220114532/https://cdn.binqmedia.nl /Woonwijs/2017/9/10/1049378240/23.jpg (laatst geraadpleegd op 9 april 2020)

Internet Archive, Wayback Machine https://web.archive.org/web/20200220114053/https://cdn.binqmedia.nl /Woonwijs/2017/9/10/1049378240/6.jpg_(laatst geraadpleegd op 9 april 2020)

Koninklijke Bibliotheek. 2020. Archief AD (én 150.000 andere kranten) toegevoegd aan Delpher. (https://www.kb.nl/nieuws/2020/archief-aden-150000-andere-kranten-toegevoegd-aan-delpher) (laatst geraadpleegd op 9 april 2020)

Koninklijke Bibliotheek. 2020. Delpher. (https://www.delpher.nl/2 (laatst geraadpleegd op 9 april 2020)

Lits-jumeaux. $\quad$ https://nl.wikipedia.org/wiki/Litsjumeaux\#/media/Bestand:WLANL_-_p_vanderree_-

_Bed_756,_W.H._Gispen_(1933).jpg (laatst geraadpleegd op 9 april 2020) 
Museum Rotterdam, inventarisnummer 30009-6. https://museumrotterdam.nl/collectie/item/30009-6 (laatst geraadpleegd op 9 april 2020)

Museum Rotterdam, inventarisnummer 79736-A-B https://museumrotterdam.nl/collectie/item/79736-A-B (laatst geraadpleegd op 9 april 2020)

Museum Rotterdam, inventarisnummer 8306. https://museumrotterdam.nl/collectie/item/8306 (laatst geraadpleegd op 9 april 2020)

Naamlijst voor den interlocalen telefoondienst 1942. januari 1942: 3490. https://resolver.kb.nl/resolve?urn=MMMVC01:000000035:00077

Pander. https://nl.wikipedia.org/wiki/Pander (laatst geraadpleegd op 9 april 2020)

Stichting Gispen Collectie.

https://www.stichtinggispencollectie.nl/collectie/producten (laatst geraadpleegd op 9 april 2020)

Wiewaswie, 2020. https://www.wiewaswie.nl/ (laatst geraadpleegd op 9 april 2020) 